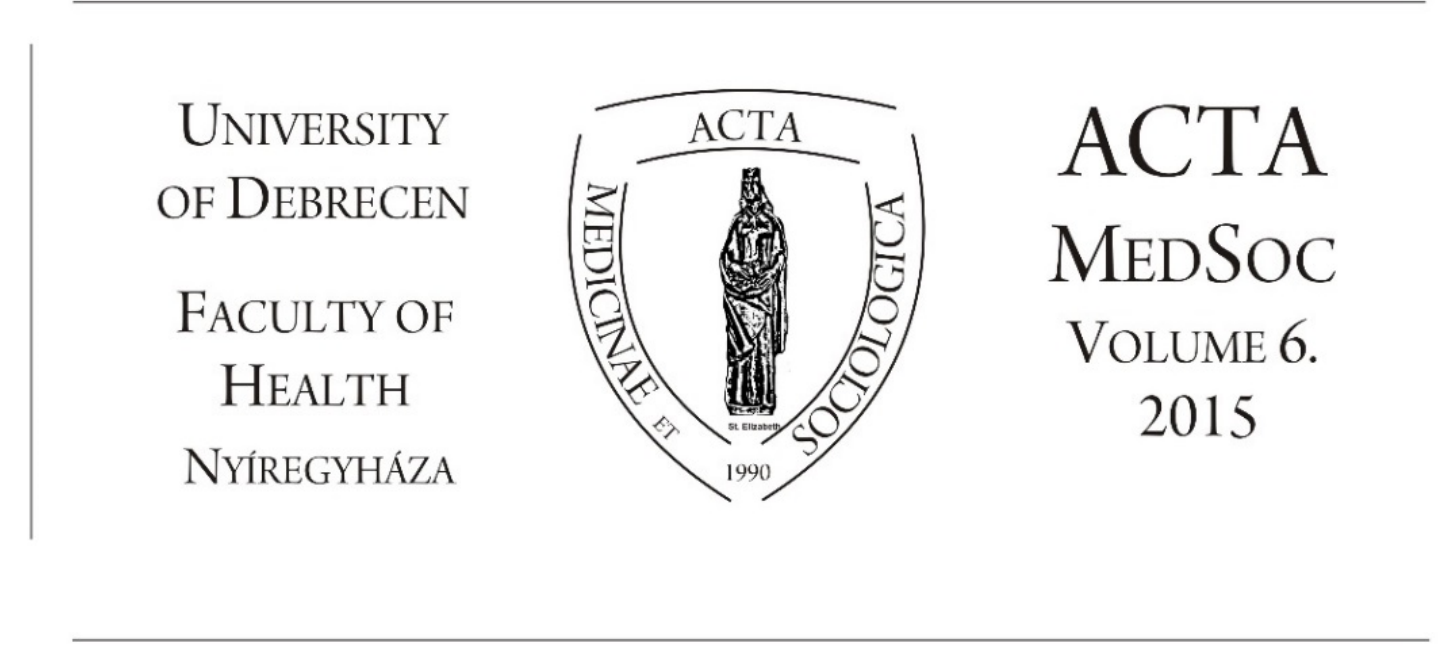

\title{
Lakásjellemzők a Nyíregyházi járásban és a megyeszékhelyen
}

\author{
Szoboszlai Katalin \\ Debreceni Egyetem Egészségügyi Kar, Nyíregyháza
}

\begin{abstract}
The aim of the study is to analyze statistical data on housing typical to Nyíregyháza and Nyíregyháza district and data in connection with housing poverty based on statistical data on housing of KSH from 2013 and on "Quality of life of Nyíregyháza 2015" research study. While analyzing the statistical data on housing of the two geographical areas it is important to take the urban features of the county seat and the basically village characteristics of the municipalities of the district into consideration.

In respect on housing stock it is important to mention that while the number of dwellings is slightly increasing there is a relatively low number of available rental housing and it is experiencing a slight decline in the county seat. As the civilization is developing, dwelling is becoming the scene of satisfying more and more human needs and it is linked with the available assets. An apartment, where people live, should have the basic conditions to satisfy human needs on the level of the recent age.

It is not given to each Hungarian person and family. They are who are not able to pay the costs of housing, who live in crowded and sub-standard apartments, who face eviction due to their currency loan debts, who live in effective homelessness. In summary they live in housing poverty. The study gives a more detailed analysis of this social problem in the examined area.
\end{abstract}

Keywords: inhabitants, housing, rental housing, housing poverty 


\section{Bevezetés}

A tanulmány célja Nyíregyháza és a Nyíregyházi járás településeire jellemző lakásstatisztikai adatok és lakhatási szegénységgel összefüggésbe hozható adatok elemzése a KSH rendelkezésemre bocsátott 2013. évi lakásstatisztikai adatai és „Nyíregyháza életminősége 2015” kutatás alapján. A két földrajzi terület lakás adatainak elemzésekor fontos figyelembe venni a megyeszékhely városi sajátosságait, illetve a járás településeinek alapvetően falusi jellegzetességeit. A lakásállomány tekintetében nem mehetünk el szó nélkül a tény mellett, miszerint amíg a lakások száma egy kevéssel növekedik, addig a relatíve kevés bérlakásállomány kismértékü csökkenésének tényével számolunk a megyeszékhelyen. A lakás, mint a civilizáció fejlődésével egyre több emberi szükséglet kielégítésének színtere, összekapcsolódik a rendelkezésre álló javakkal. A lakásnak, ahol élünk, az emberi szükségletek kielégítésének elemi feltételeivel a jelenkor színvonalán kellene rendelkeznie. Ez nem adataik meg minden embernek és családnak Magyarországon. Ök azok, akik nem képesek kifizetni a lakhatás költségeit, akik zsúfolt és komfort alatti, szubsztandard lakásokban élnek, akiknek devizahitel tartozásaik miatt a kilakoltatással kell számolniuk, és akik effektív hajléktalanságban élnek. Összefoglalva, ők élnek lakhatási szegénységben. A tanulmány ezt a társadalmi problémát részletesebben elemzi a vizsgált területre vonatkozóan.

\section{A lakónépesség és a lakások jellemzői a megyeszékhelyhez tartozó járásban és Nyíregyházán}

A Nyíregyházi járáshoz 4 városi és 11 községi besorolású település tartozik. A járáshoz tartozó települések a megyeszékhely vonzásában találhatók, aminek előnyeit több szempontból élvezik a településeken élők. A járási települések lakosainak munkavállásra képes lakosai nemcsak dolgoznak Nyíregyházán, hanem gyakran gyermekeiket is a megyeszékhely iskoláiba járatják, és ezek miatt naponta beutaznak Nyíregyházára. (Malakucziné, 2015)

Az alvótelepülések sajátosságai fedezhetők fel a járási településeken, mivel a lakosság egy részének a lakások funkciói túlnyomórészt a pihenést, a feltöltődést, a családi együttlétet szolgálják jellemzően az esti és a hétvégi időszakban. Alvó településekre jellemző vonás ezenkívül, hogy e települések lakosságának fogyasztási szokásai rendszerint a nagyváros infrastruktúrájához és szolgáltatásaihoz kapcsolódnak, ezért különösen ritka és alacsony színvonalú a szolgáltatások jelenléte és fejlettsége a községekben. 
1. sz. ábra: Lakónépesség és lakásállomány adatai, 2014.

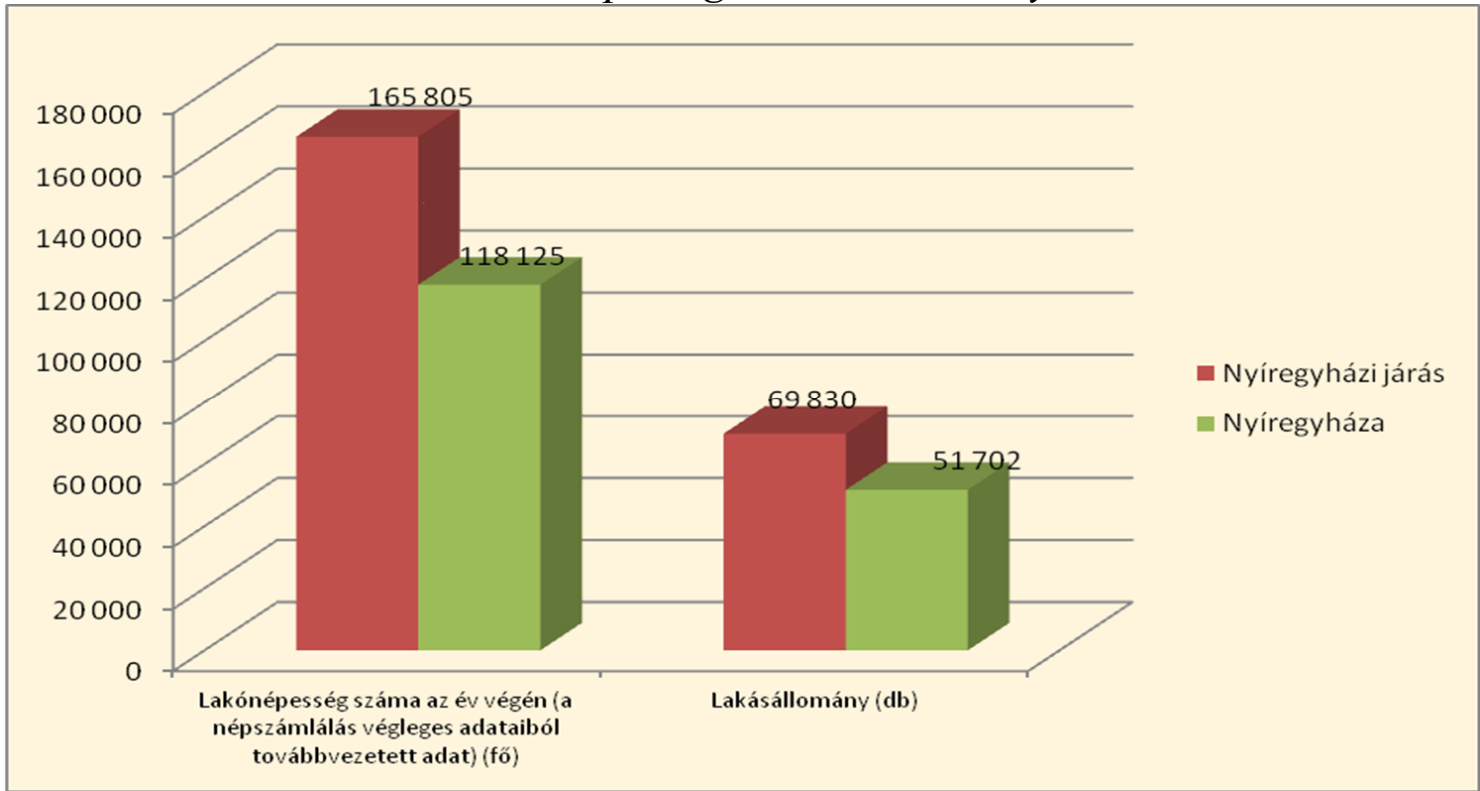

Forrás: KSH, 2013.

Miközben Nyíregyháza lakónépessége több mint 118 ezer fó, addig a járási települések lakossága 47.680 fó volt 2013-ban. A járási populáció tartalmazza a legnagyobb lakosságszámú település, Újfehértó tizenkétezer fős lakosságát és az alig néhányszáz fös Szabolcs község népességét. (Malakucziné, 2015)

A Nyíregyházi járás lakásállománya megközelíti a 70 ezret, ebből körülbelül 52 ezer lakást a megyeszékhelyen találunk 2013-ban.

2. sz. ábra: Lakásállomány és épített lakások száma

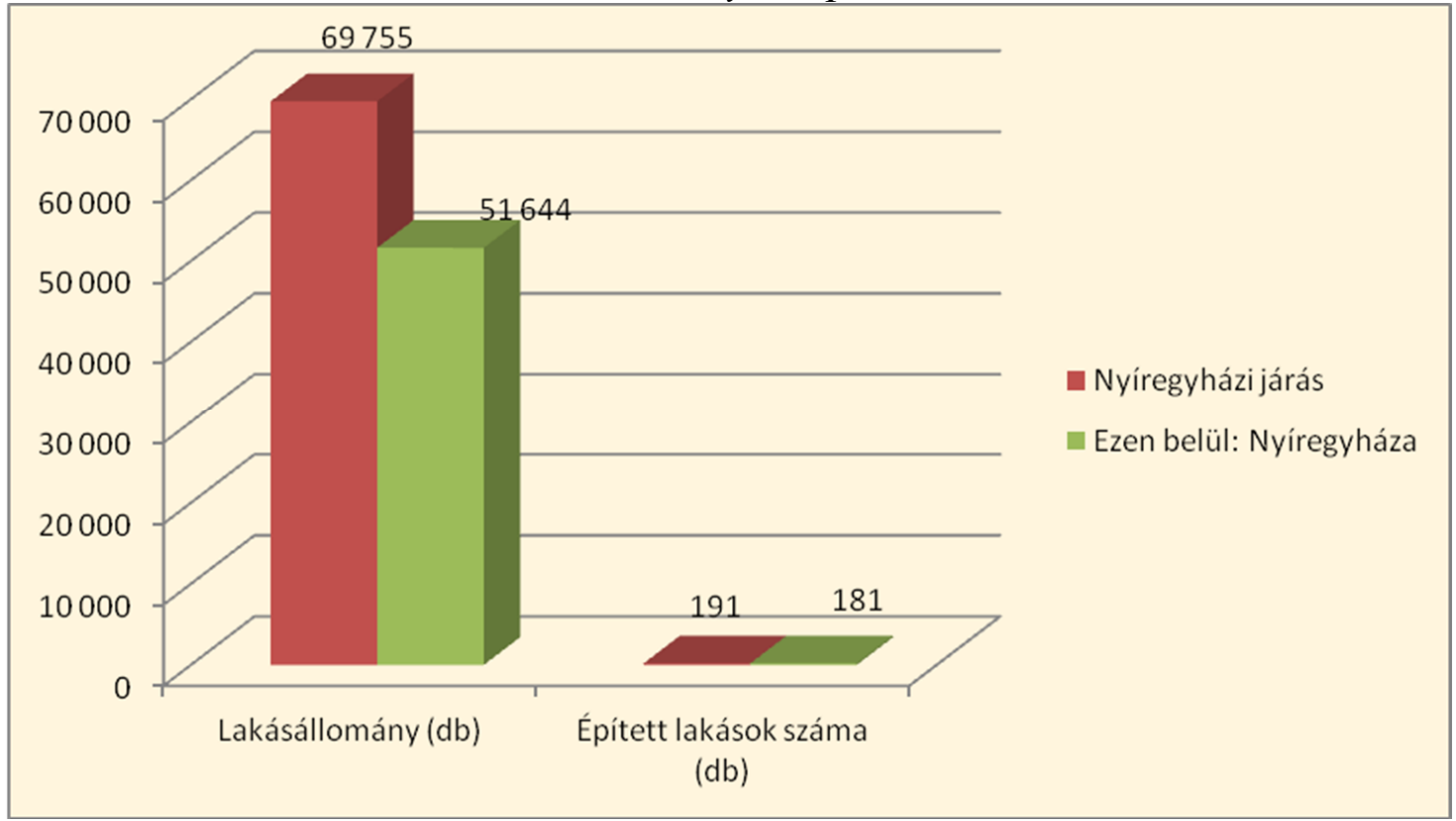

Forrás: KSH, 2013. 
A lakásépítés mélyrepülése érzékelhető az országban és a vizsgált területeken. A gazdasági válság elsők között fordította negatívba az ingatlanpiacot és az építőipart. A természetes személyek, a vállalkozások és az önkormányzatok által épített lakások számában jelentős csökkenés következett be 2008. év után. Mind a megyeszékhelyen, mind a járás településein a lakásépítési kedv néhány éve meglehetősen alacsony, éppen ezért csekély emelkedés látható a lakásállományban a vizsgált területeken. A járás településein $10 \mathrm{db}$ új lakás épült 2013-ban. A megyeszékhelyen $181 \mathrm{db}$ épített lakással 0,3 százalékban érhető tetten a meglévő lakásállomány bővülése, ami a természetes személyek által épített családi házaknál és a vállalkozások által épített társasházi lakásoknál jelentkezik. (2. sz. ábra)

3. ábra: A 2013. év folyamán épitett lakóépületek száma és típusa, Nyíregyházi járás $(d b)^{5}$

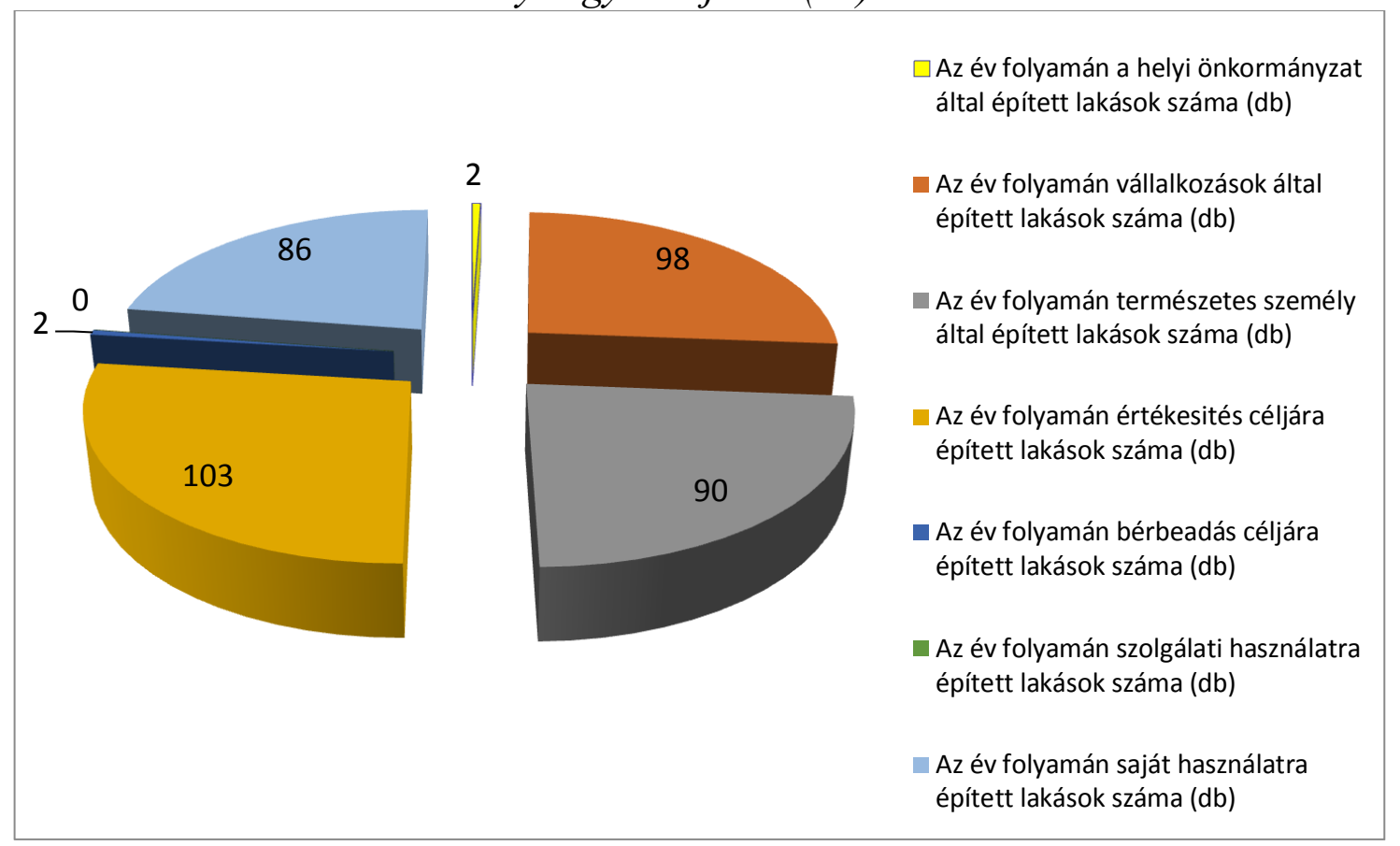

Forrás: KSH, 2013.

Önkormányzati lakás és bérbeadásra szánt lakás építésére Újfehértón került sor, ahol kettő bérlakás épült fel 2013-ban. Ilyenfajta típusú lakásépítés a megyeszékhelyen nem történt, a központi településen jellemzően eladásra és saját használatra építettek lakásokat az év folyamán.

\footnotetext{
${ }^{5}$ A Nyíregyházi járás adatai a megyeszékhelyen épült lakások adatait is tartalmazzák.
} 
4. sz. ábra: 2013. év folyamán épített lakások közmüellátottsága

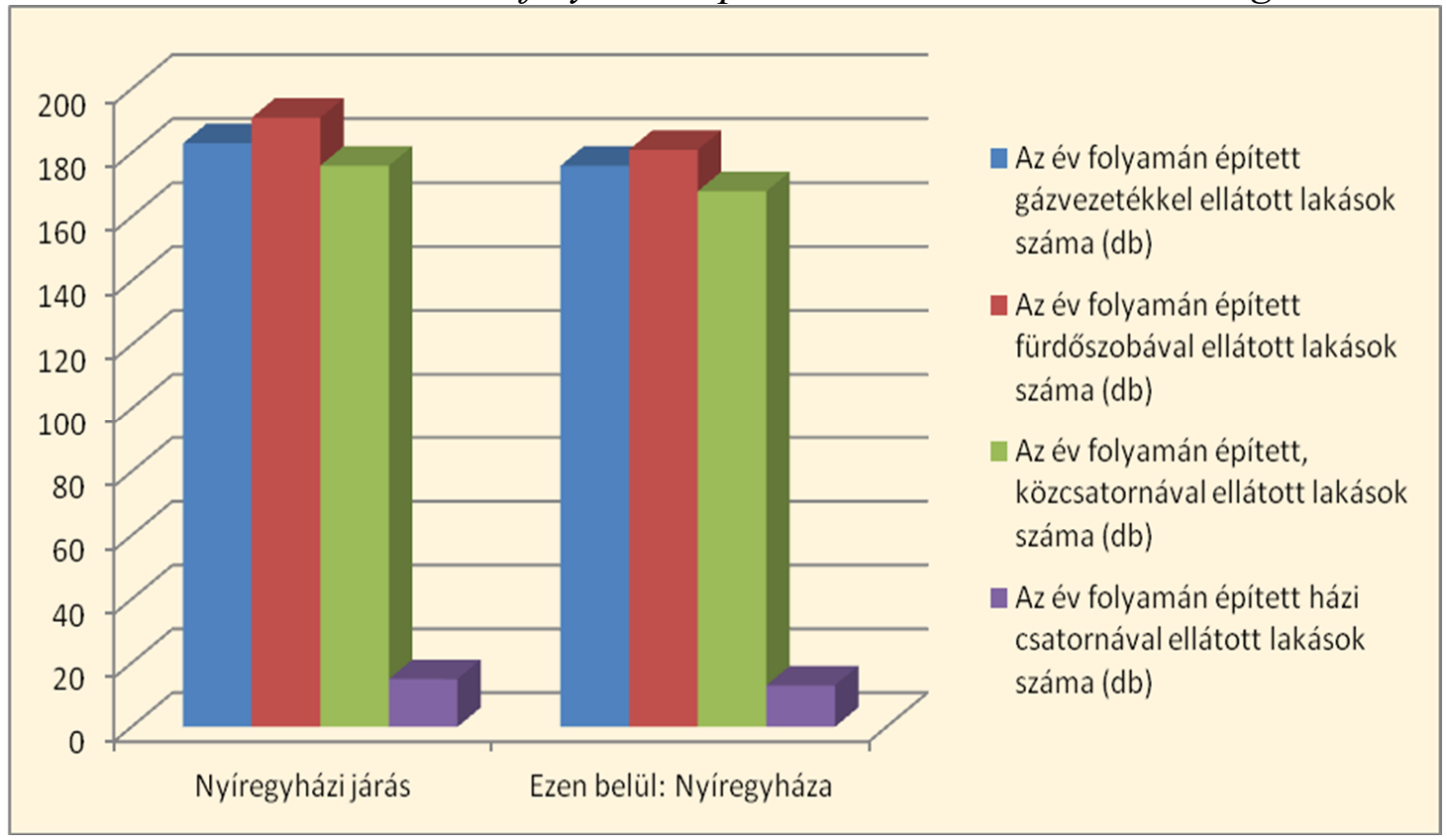

Forrás: KSH, 2013.

Az újonnan épített lakások közmüellátottsága a jelenkor színvonalának megfelelö, ezek a lakások összkomfortosok, mindegyik gázvezetékkel, fürdőszobával és közmücsatornára történt csatlakozással ellátott lakóépület a megyeszékhelyen és a járás településein.

5. sz. ábra: A lakások komfortja

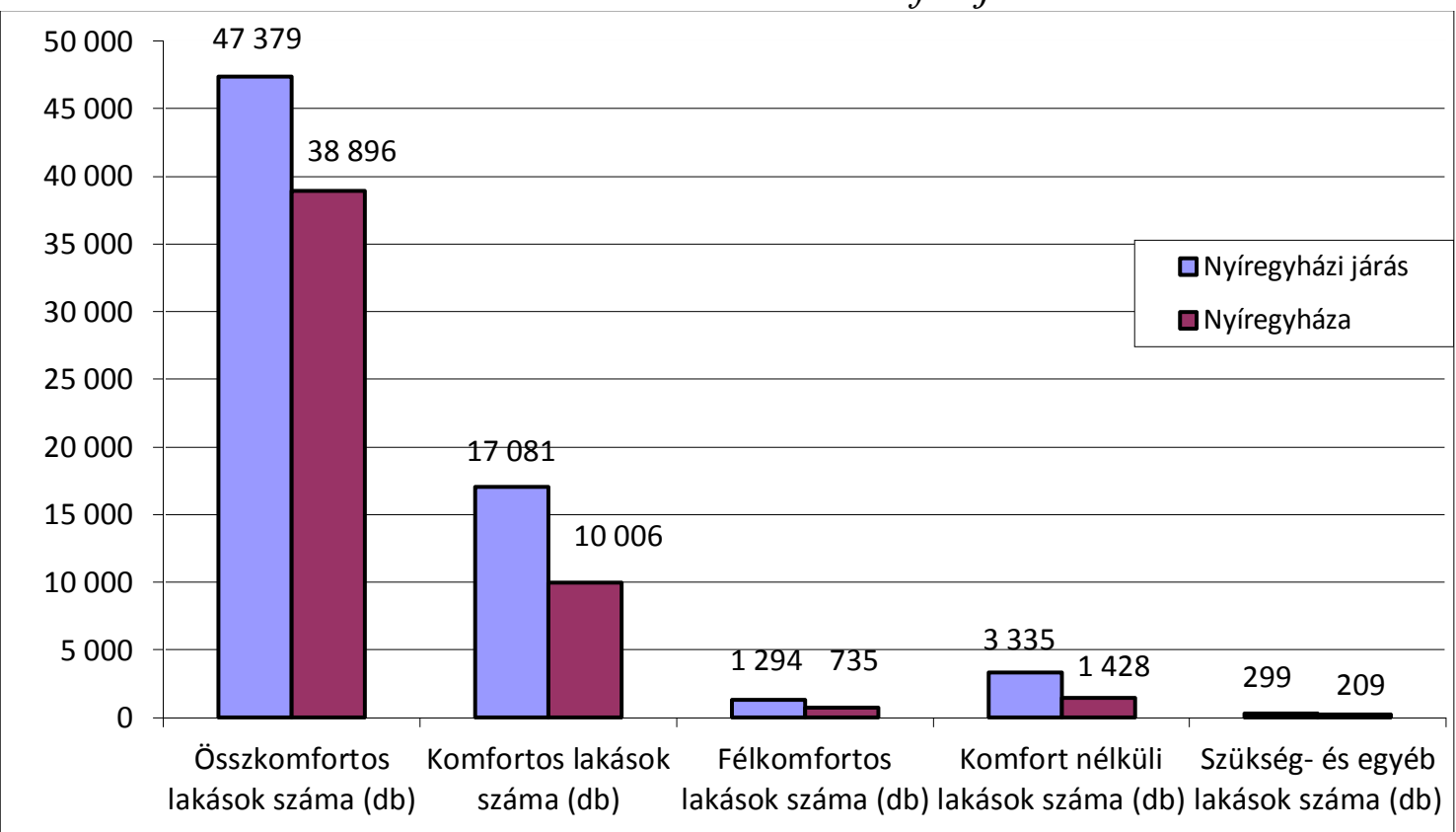

Forrás: KSH, 2013. 
A járás településein, beleértve a megyeszékhelyet is, a lakásállomány kétharmada összkomfortos lakásokból áll. Nyíregyházán még ennél is jobbak az adatok, mivel a lakások háromnegyede összkomfortos lakás, ahol legalább egy $12 \mathrm{~m}^{2}$-t meghaladó alapterületü lakószoba, főzőhelyiség, fürdőhelyiség és WC található a lakásban, valamint közmüvesített, melegvíz-ellátás biztosított és központos fütési móddal rendelkezik. ${ }^{6}$

A lakásállomány megközelítően 3 százaléka komfortnál rosszabb minőségü lakás a járás településein. Nyíregyházán a lakásállomány 4,5 százaléka nem eléri el a komfortos minősítést. Ezekben a félkomfortos, komfortnélküli és szükséglakásokban élőknél jelentkezik a zsúfoltság, a lakásban nincs fürdőhelyiség, a WC helyett, lakáson kívüli árnyékszéket találunk, hiányos a közmüellátottság és egyedi fütési mód jellemzi.

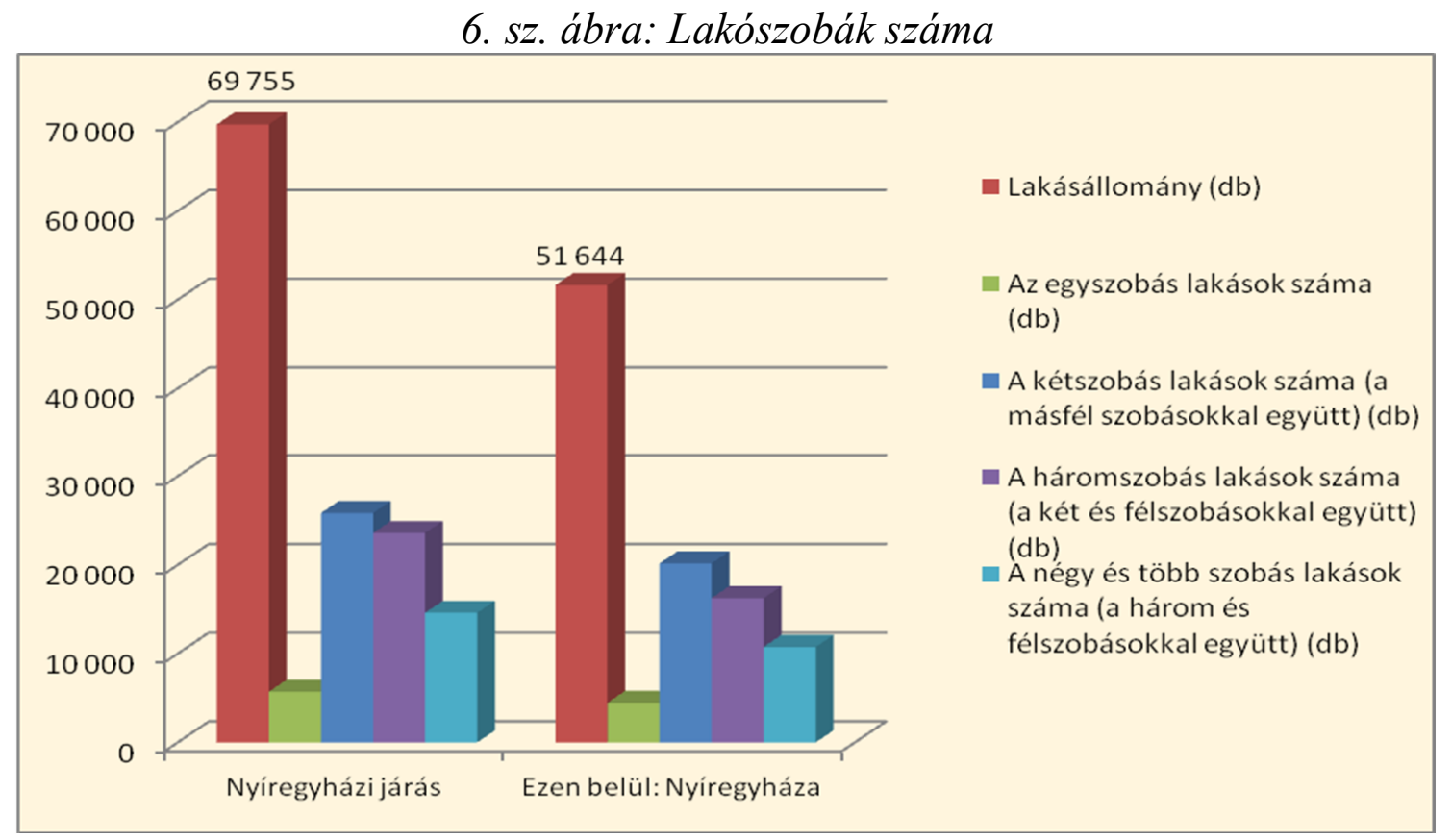

Forrás: KSH, 2013.

A lakások szobaszámát tekintve jellemzően kettő és háromszobás lakásokban élnek a családok a járás településein. Az egy, valamint a négy és több szobás lakások többségében a megyeszékhelyen találhatók. Közülük az egyszobás lakások nagyvárosi sajátosságként jelentkező panellakások övezeteiben fordulnak elö, míg a négy és több szobás lakások a családi házas lakóterületek közül nagyrészt a kertvárosi típusú lakóterületeken jellemzőek.

\footnotetext{
${ }^{6}$ A komfortfokozat meghatározása a wikipédián közölteket tartalmazza: https://hu.wikipedia.org/wiki/Komfortfokozat
} 
1. sz. táblázat: Lakások tulajdonosi jellemzöi (\%)

\begin{tabular}{|l|c|c|c|}
\hline & $\begin{array}{c}\text { Nyíregyháza } \\
\text { járás összesen }\end{array}$ & $\begin{array}{c}\text { Nyíregyházi } \\
\text { járás }\end{array}$ & Nyíregyháza \\
\hline Saját tulajdon & 89.5 & 91.5 & 87.1 \\
\hline Bérelt lakás & 4.5 & 1.5 & 8.0 \\
\hline Önkormányzati bérlemény & 1.0 & 0.1 & 1.9 \\
\hline $\begin{array}{l}\text { Más tulajdona (szívességi } \\
\text { lakáshasználat) }\end{array}$ & 2.0 & 2.6 & 1.2 \\
\hline Egyéb & 3.0 & 4.3 & 1.8 \\
\hline
\end{tabular}

Forrás: Nyíregyháza Életminösége 2015.

A lakástulajdonok tekintetében a struktúrák nem változtak a megelőző adatfelvételekhez képest. (Szoboszlai, 2014) Mindkét területi adat jól mutatja a saját tulajdonú lakások felülreprezentált jellegét, valamint az önkormányzati bérlemények roppant alacsony arányát a lakásállományban. A bérelt kategóriát jelentő piaci áron bérbe adott lakások 8 százalékban jelentenek alternatívát a saját tulajdonú lakások mellett a lakásban éléshez a megyeszékhelyen. Az önkormányzati bérlakások 2 százalék körüli aránya éppen azoknak a családoknak nehezíti meg a lakhatását, akik jövedelmük alapján sem önerőből, sem hitelből nem képesek maguknak lakást építeni. Önkormányzati bérlakás egyetlen darab sem épült 2012. és 2014. között Nyíregyházán. (4. sz. ábra)

\section{Lakhatási szegénység}

Lakhatási szegénységről olyan településeken fontos beszélni, ahol létező probléma a hajléktalanság, és ahol a lakáskörülmények nem jelentenek elegendő védelmet a lakásban élöknek bizonyos lakókörzetekben. Célzott vizsgálat sem a járás településein, sem a megyeszékhelyen nem történt, mégis a rendelkezésemre álló adatokból a lakhatási szegénység egyes elemeire rávilágítva, a lakhatási problémákkal kapcsolatos helyi cselekvések megfogalmazásához segítséget jelenthet az alábbi elemzés.

A lakhatás lényeges szerepet játszik az emberi szükségletetek kielégítésében. A lakhatás védelmet jelent a környezeti ártalmaktól, biztonságot nyújt és tere a reprodukciónak, a regenerálódásnak és a társas együttlétnek. A lakhatás pontosan ezért nem müködhet pusztán piaci alapon kiszolgáltatva az embereket, a családokat a jövedelem és a vagyon által megteremthetö lakhatásnak. A modern társadalmak elsődleges szükségletnek tekintik a lakhatást, amit az Emberi Jogok Európai Bírósága is elfogadott annak a ténynek a megállapítása mellett, hogy az ENSZ Emberi Jogok Nyilatkozata (továbbiakban: egyezmény) nem sorolja a lakhatást az alapjogok közé, mégis hozzáteszi, hogy a modern államok nem tehetnek elviselhetetlen életkörülményeket az emberekre, családokra a lakhatással kapcsolatosan. A megfelelő életszínvonalhoz való jog előfeltétele többek között a 
mindenkit megillető lakhatáshoz való jog. ${ }^{7}$ Az Európai Szociális Charta mindezek alapján főleg a családok, a migránsok, az idősek és a hajléktalanok lakhatáshoz való jogát védelmezi.

Magyarország Alaptörvénye nem tartalmazza a lakhatáshoz való alapjogot. Az ENSZ Gazdasági, Szociális és Kulturális Jogok Bizottsága deklarálta a megfelelő lakhatás fogalmát, amit minden, az egyezményt elfogadó államnak használni kellene a lakhatásról szóló jogban és szociális politikában. Ennek hiányában a biztonságos és minőségi lakásban élés kívánalmainak érvényesítése sok problémákat vet fel hazánkban.

A lakhatási szegénység fogalmi meghatározásához fontos tisztázni a megfelelő lakhatás összetevőit. A tipológiát összeállította, és a fogalmat kutatásokkal együtt évek óta mélyrehatóan vizsgálja a Habitat for Humanity ökumenikus szervezet Magyarországon. ${ }^{8}$

A Habitat for Humanity az ENSZ Gazdasági, Szociális és Kulturális Jogok Bizottsága által meghatározott megfelelö lakhatás fogalomból indul ki a hazai viszonyokra adaptálva. Eszerint a megfelelő lakhatás a következőkre terjed ki:

- „A lakhatás jogi biztonsága: védelem az erőszakos kilakoltatás, zaklatás és egyéb fenyegetések ellen.

- Lakásminőség: az egészség megőrzését, biztonságot, komfortot, táplálkozást lehetővé tevő alapszolgáltatásokhoz és infrastruktúrához való hozzáférés (ivóvíz, energia, szanitációs lehetőségek ${ }^{9}$, ételtárolás, szemétszállítás, sürgősségi ellátások), valamint a lakhatás jellemzői (megfelelő alapterület, hideg, nedvesség, eső, szél, egyéb egészséget veszélyeztető tényezők elleni védelem).

- Megfizethetöség: a lakhatással kapcsolatos költségeknek olyan szinten kell lenniük, hogy más alapvető szükséglet kielégítését vagy megszerzését ne veszélyeztessék. A nemzetközi szakirodalom a háztartás bevételeinek 3035 százalékát elérő vagy meghaladó lakhatási költségek esetén megfizethetőségi problémáról beszél.

- Elhelyezkedés: a megfelelö lakásnak olyan helyen kell lennie, amely lehetővé teszi a munkába járást, valamint egészségügyi szolgáltatások, iskola és egyéb szociális szolgáltatások igénybe vételét, magyarországi kontextusban emellett a megfelelő elhelyezkedésü lakás kritériumának tekintjük a társadalmi integrációt és mobilitást lehetővé tevő társadalmi környezetet is.

- Speciális igényekkel rendelkezö, elesett csoportok hozzáférése a megfelelö lakhatáshoz” (pl. idősek, gyerekek, mozgáskorlátozottak, hajléktalanok, természeti katasztrófák áldozatai).

\footnotetext{
${ }^{7}$ Az ENSZ Emberi Jogok Egyetemes Nyilatkozata és a Gazdasági, Szociális és Kulturális Jogok egyezségokmánya alapján állapította meg az Emberi Jogok Európai Bírósága.

${ }^{8}$ Bővebben a szervezetről: http://www.habitat.hu/

${ }^{9}$ Szanitáció a szennyvíz elhelyezést jelenti.
} 
Mindezek alapján „, a lakhatási szegénység olyan lakáskörülményeket jelent, amelyek között nem teljesülnek a megfelelö lakás kritériumai, így például megfizethetöségi problémák merülnek fel, nem biztositott az alapszolgáltatásokhoz és infrastruktúrához való hozzáférés, minöségi vagy mennyiségi értelemben nem kielégitö (kis alapterületü, nem füthetö megfelelöen, felújitást igényel stb.), vagy rossz elhelyezkedésü a lakás (például a szolgáltatásokhoz, infrastruktúrához nincs megfelelö hozzáférés, vagy rossz a szociális környezet)." (Habitat for Humanity, 2013.)

A lakásépítés és megfelelő komfortfokozatú lakások építése alapvetően nem tartozik az állami és az önkormányzatok feladatkörébe a rendszerváltás után. Az államnak huszonöt éve nincs lakáspolitikai stratégiája, és hasonlóképpen nem jellemző a települési önkormányzatok koncepcionális tervezése és cselekvése a lakhatás vonatkozásában. Többségben magánszemélyek, családok, vállalkozások lakásépítése volt jellemző az elmúlt évtizedekben Magyarországon. Minden lakásstatisztikai adat megerősíti ezt a tényt a lakások tulajdoni szerkezetére vonatkozóan. Bérlakásépítésre fordított állami és önkormányzati kiadás roppant kevésnek bizonyul. Az állam a költségvetés forrásait elsősorban a lakásban élés elösegítésére, a lakásfenntartás kiadásainak fizetésére, a rezsi és devizahitel tartozás csökkentésére, lakáscélú szociálpolitikai kiadásokra és a hajléktalan ellátásra fordította 2013-ban.

A lakhatáshoz kapcsolódó állami kiadások között 1,5 milliárd forint összegü ráfordítás található bérlakásépítésre 2013-ban. Ezek a lakások az ócsai lakóparkban épültek fel a devizahitellel terhelt lakásokban élők lakhatásának biztosítására bérlakásokban. ${ }^{10} \mathrm{Az}$ állami bérlakásépítés nyilvánvaló hiánya az önkormányzatok lakásépítésével lenne pótolható, amit az önkormányzatoknak saját forrásaik terhére kellene biztosítaniuk.

Napjainkban a teljes magyar lakásállomány nem egészen 3 százaléka önkormányzati bérlakás, mely lakások a fővárosban és a vidéki nagyvárosokban koncentrálódnak. A 10 ezer fö alatti településeken átlagosan 1 százalékos a bérlakásállomány, és közel 700 településen egyetlen bérlakás sem található. A bérlakásban élők közül az önkormányzati bérlakást jellemzően egyedülálló szülők gyermekkel (8 százalék), 65 év alatti egyedülállók (5 százalék) és párok gyermekkel (4 százalék) veszik igénybe. Az önkormányzati bérlakást használók lakásmobilitási lehetőségei roppant kedvezőtlenek, az igénylők rendszerint több évet várnak a bekerülésre, majd a minőségi lakáscserére. Az önkormányzati bérlakásban élők egy főre jutó jövedelmi helyzetét tekintve a lakáshasználók 11 százaléka az 1. jövedelmi decilisbe tartozik, ezzel a legnépesebb csoportot alkotják. Ök azok a szegények, akiknek a bevételei messze nem elegendőek piaci alapú bérlakás költségeinek kifizetésére, illetve lakásépítésre, vásárlásra. Ugyancsak az egy före eső jövedelem alapján az önkormányzati bérlakásban élők 24 százaléka az 1-4. jövedelmi decilisbe

\footnotetext{
${ }^{10}$ A lakóparkban 80 lakás épült, ahol 79 család és mintegy 350 fö lakott 2015. januárban. A központi költségvetésböl összesen 2,5 milliárd forintot fordított a devizahiteleseknek szánt lakhatás biztosítására az állam a 2015-ös adatok alapján.
} 
tartozik, ami azt jelenti, hogy a szegények mellett az elszegényedők és a lecsúszók lakhatásában is jelentős szerepet játszik az önkormányzati bérlakás. (KSH, 2010.)

2. sz. táblázat: Szociális lakásgazdálkodás (\%)

\begin{tabular}{|l|c|c|c|}
\hline Önkormányzati lakások aránya a régiókban & 2005 & 2010 & 2015 \\
\hline Közép-Magyarország & 5,2 & 4,1 & 3,6 \\
\hline Dunántúl & 3,2 & 3,0 & 2,7 \\
\hline Alföld és Észak & 2,8 & 2,5 & 2,3 \\
\hline
\end{tabular}

A táblázat az önkormányzati tulajdonú lakásállomány arányait mutatja be az összes lakás százalékában, január 1-jén. (2. sz. táblázat) $\mathrm{Az}$ adatok a szociális lakásgazdálkodás mozgásterét jelzik, ami alapján megállapítható, hogy az egész országban a bérlakás állomány változása a tendenciát tekintve csökkenést mutat a relatíve 2005-ben is alacsony mértékü bérlakás állományhoz képest, tíz év alatt minden földrajzi területen. Szembetűnően kevés az Észak-alföldi és ÉszakMagyarországi régiókban található, együttes adatokkal közölt bérlakásállomány. Az ország társadalmi egyenlőtlenségek vonatkozásában leghátrányosabb területein a lakásállomány mindösszesen 2,3 százaléka tekinthető önkormányzati bérlakásnak.

Mindezek alapján joggal kereshetjük azokat a lakhatási lehetőségeket, melyeket az élethelyzetüknél fogva speciális helyzetben élők közül a hajléktalanoknak és a lakhatás költségeket a legkevésbé megfizetni képeseknek jelentene emberhez méltó lakhatást.

\section{Bérlakás jellemzők Nyíregyházán}

Az önkormányzati bérlakásban élők jövedelmi helyzetét tekintve a fent említett országos adatokhoz hasonlítva a megyeszékhely lakosságának egy före jutó jövedelmét, a legutóbbi panelkutatás eredménye alapján a legkevesebb jövedelemmel rendelkezők havi bevétele kevesebb mint 30 ezer forint, és a 4. decilisbe tartozók jövedelme nem több mint 62,5 ezer forint havonta Nyíregyházán. (FábiánTakács-Szigeti, 2015)

Ezek alapján a lakhatás költségeinek kifizetése relatíve alacsony költséggel terhelt lakásokban megvalósítható, amibe beletartozhatnak azok az önkormányzati bérlemények, melyek komfort vagy komfort alatti minőségüek.

Az önkormányzat kezelésében lévő bérlakás-állomány többnyire 1990 előtt épült Nyíregyházán. A bérlakás-állományban érzékelhető növekmény a Lobogó utcai lakások felépítésével történt a közelmúltban. Mind a 114 lakás ún. „Fecske” lakás, ami lakhatási megoldást jelent azoknak a kisgyerekes családoknak, akik képesek élőtakarékossággal belátható időn belül saját lakásba továbblépni.

11 A teljes adatsor 2003. - 2015. évekre vonatkozóan itt található meg: http://www.ksh.hu/thm/2/indi2_7_7.html 
Nyíregyháza városban 1,921 darab önkormányzati bérlakást tartanak nyilván. Ez az összes lakásállomány 3,7 százaléka. A bérlakás kezelő adatai alapján az igénylők száma még egyszer annyi, mint a használatban lévő lakások száma. Jelenleg mintegy 1,900 fő várakozik bérlakásra a városban. ${ }^{12}$

7. sz. ábra: Bérlakások területi jellemzői Nyíregyházán (darab) $)^{13}$

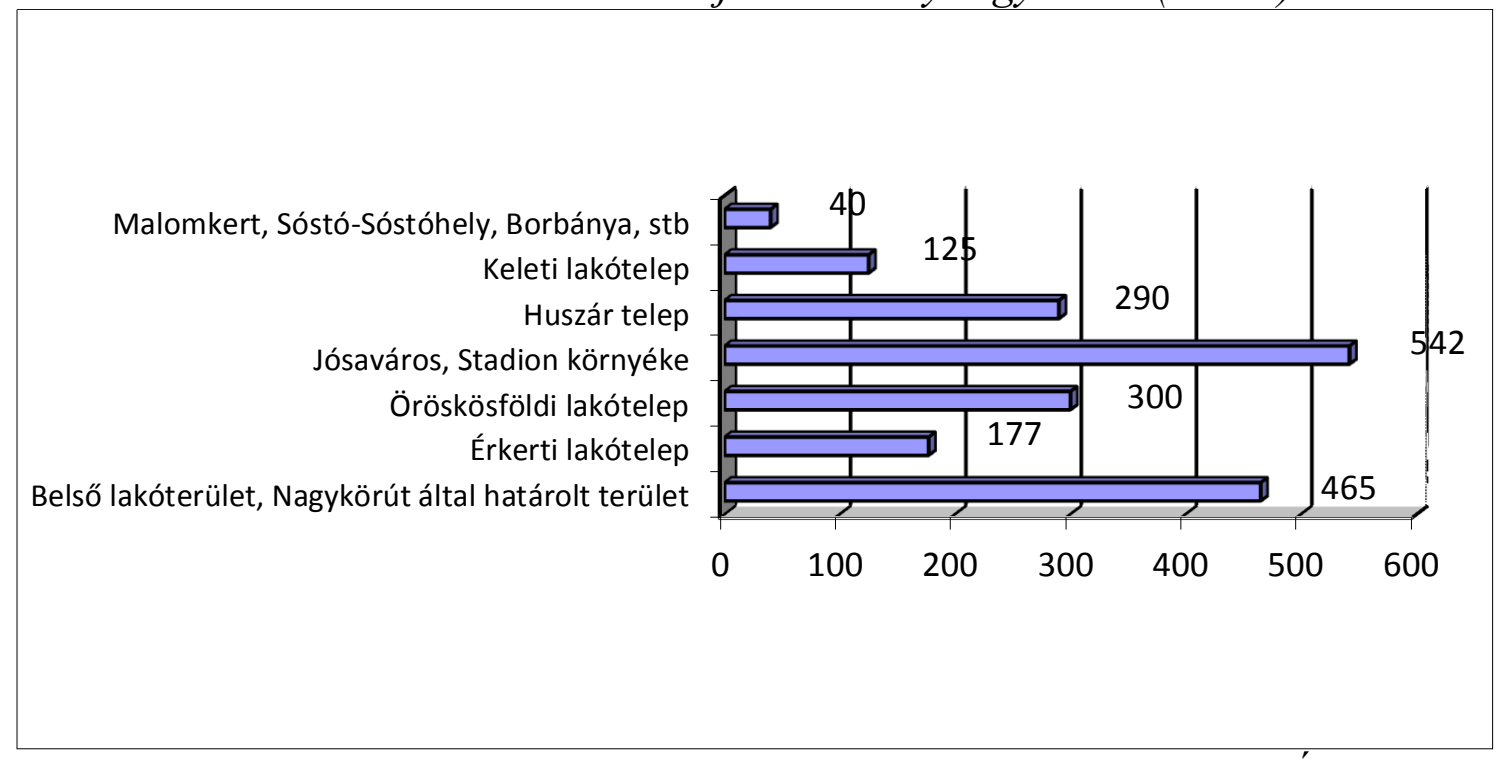

Forrás: NYÍRVV, 2011.

A nyíregyházi bérlakások 22 százaléka a város két szegregátumában, a Huszár telepen és a Keleti lakótelepen található. Mindkét lakóterületen jellemző a cigány családok és a szegénység koncentrált jelenléte. ${ }^{14}$ (Szoboszlai, 2014) Mindkét lakóterület lakosságának gazdasági és társadalmi adatai lényegesen rosszabbak, mint a város más területein. Mindkét lakótelepen a lakásállomány többnyire önkormányzati bérlakásokból áll, melyek főként komfort alatti besorolásúak. Ezeknek a lakásoknak az állapota lakhatásra a legkevésbé sem alkalmas. Ezt felismerve a város lakóterületi rehabilitációs programban megkezdte a rossz infrastruktúrájú, leromlott lakások részleges felújítását a Huszár telepen. Ebben az Európai Unió által támogatott programban nyílászáró cserére, homlokzat és tetőzet felújításra került sor mintegy 82 lakásnál, és belső felújítás is történt néhány lakás esetében. A Keleti lakótelep lakásainak szanálása abban az esetben lenne megoldható, ha sikerülne az ott élők lakhatásról gondoskodni az önkormányzatnak. Ezen a lakóterületen az üressé vált lakásokat lezárja a házkezelő vállalat, bérbeadásukra nem kerül sor a továbbiakban.

\footnotetext{
${ }^{12}$ Nyíregyházi Városüzemeltető és Vagyonkezelő Nonprofit Kft. (NYÍRVV) adatai alapján nem teljes körüen.

${ }^{13} \mathrm{Az}$ ábra nem tartalmazza az összes bérlakás helyét a városban. A legismertebbek kerültek megnevezésre.

${ }^{14}$ Cigánynak nevezett emberek a környezet megítélése alapján.
} 


\section{8. sz. ábra: Bérlakások komfortfokozata Nyíregyházán (\%)}

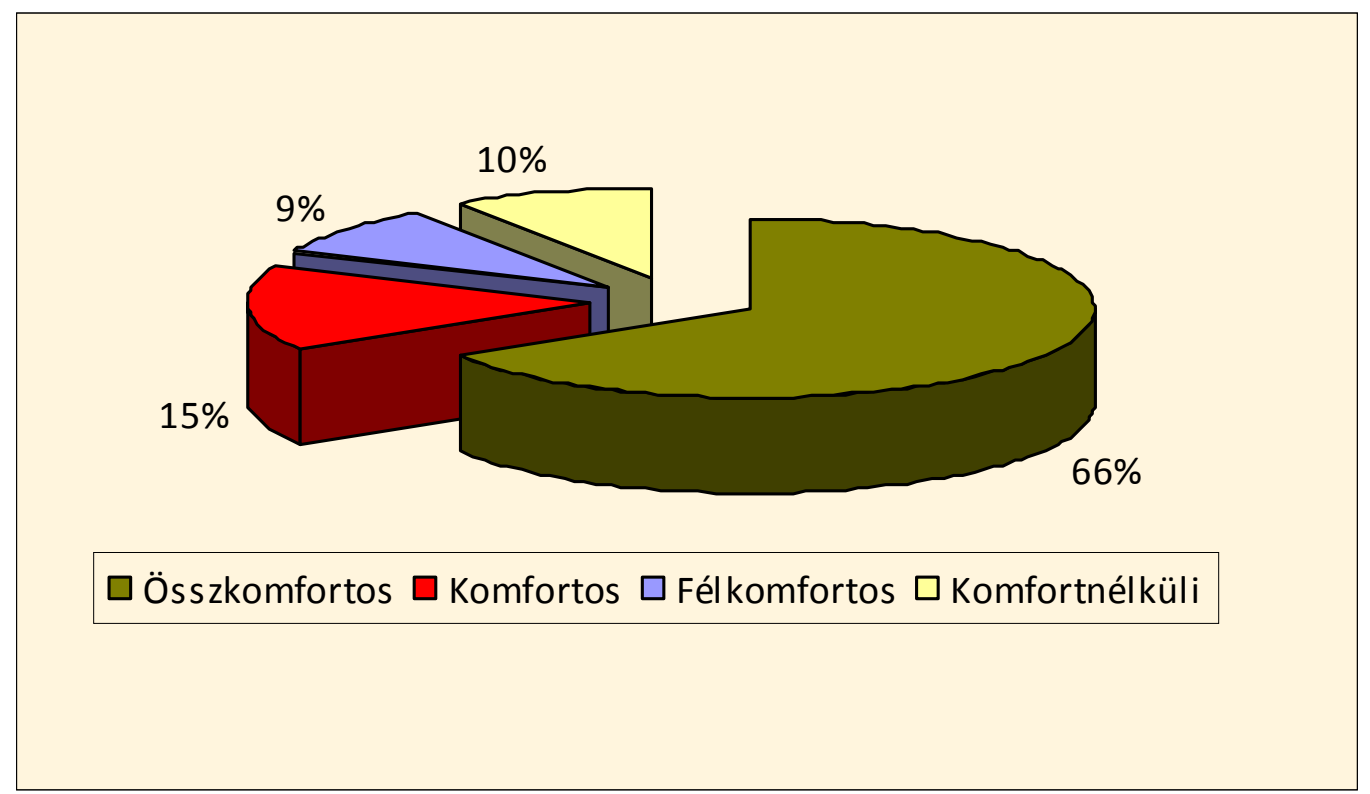

Forrás: NYÍRVV, 2015.

A városi bérlakások komfortja a lakások kétharmadánál a jelenkor színvonalának megfelelő, ezek a lakások WC-vel, hideg-meleg vízzel, fürdőszobával, gáz vagy távhő fütéssel rendelkeznek. A bérlakások egyötödében a komfortosság tekintetében súlyos hiányosságok vannak, melyek megnehezítik a lakásban élést. Ezeknek a lakásoknak egy részében nem találunk vezetékes vizet, fürdőszobát, a fütést egyedileg oldják meg télen, rendszerint adományba kapott kályhákkal. Komfortnélküli bérlakásokat a Huszár telepen és a Keleti lakótelepen találunk a legnagyobb arányban. A város belső és integrált lakóterületein található bérlakások komfortosságában meghatározó a társasházi és panelépítés, ez utóbbi az Ungvár sétányon található 190 lakást jellemzi. Ezeknek a lakásoknak elemi hátránya a kisalapterület, ahol az élettér egy fö számára talán elegendő lenne, itt azonban föként gyerekes családok laknak 20 négyzetméteres lakásokban.

A város bérlakás állománya alapvetően kevésnek bizonyul az igénylőket tekintve. 2014. december 31. napján összesen 1,950 lakásigénylőt tartottak nyilván, akik közül 1,421 igénylő az első bérlakását igényli, és 529 fö minőségi cserével szeretne a szükségleteket jobban kielégítő bérlakáshoz jutni. Lakásigénylést - a jelenleg hatályos önkormányzati rendelet szerint - ingatlantulajdonnal nem rendelkező kérelmezők nyújthatnak be. Az igénylök átlagosan 4-5 évet várnak első bérlakásukra a megyeszékhelyen, és minőségi lakáscserére is hasonlóképpen sokat kell várni.

Kérdéseket vet fel és válaszokat kíván a devizahitelt fizetni nem tudó családok önkormányzati bérlakáshoz jutása. Ezzel kapcsolatban adatokat nem találtam, azonban várhatóan ők is igénylőként jelennek meg az önkormányzatnál. Hasonlóan megoldatlan a közterületen élő és szálláshasználó hajléktalanok lakhatása önkormányzati bérlakásban. A hajléktalanságból történő kivezető utak mindegyike a lakhatás stabil formájának kialakításával kezdődik. A megvalósításhoz a célcsoporthoz tartozók szegénységéből kiindulva önkormányzati bérlakásokra lenne 
szükség. Jelenleg 170 üresen álló önkormányzati kezelésben lévő bérlakás van a városban. Ezeknek a lakásoknak a közösségi típusú felújításával esélyt lehetne adni a hajléktalanok újrakezdéséhez. A „Habitat for Humanity” szervezet mintaprogramjai alapján a közösségi típusú lakásfelújítás civil kezdeményezésre történik az állampolgárok, a lakhatást igénylők és az önkormányzat bevonásával. Hasonló példát találunk „A Város Mindenkié” csoport fővárosi hajléktalanokat segítő munkájában is. ${ }^{15}$ A lakásban élés kiteljesítéséhez szükséges lenne az önkormányzat lakáspolitikáját összefoglaló koncepció kialakítása, melyben a megfizethető és komfortos bérlakások számának gyarapodásával együtt a lakhatásból kint rekedtek is esélyt kapnak az emberhez méltó lakában élésre.

\section{A nyíregyházi és a járásban található lakások állapota és a lakókörnyezet jellemzői}

A lakosság általában nem panaszkodik a lakások állapotára. Minkét mintában hasonló eredményeket találunk. A lakosok nem említettek olyan problémát, a lakásállomány több mint négyötödében, ami a mindennapi életvitelre kedvezőtlen hatással lenne. A fennmaradó egyötöd esetében a lakások állapotában és állagában a nyugodt életet megrontó tényezők az említés gyakoriságát tekintve a következők voltak: zajos, dohos, vizes, gombás és rossz levegőjü lakás. Árnyalatnyi különbséget lehet találni a nyíregyházi és a járási mintákban az egészségtelen lakáskörülményekre. Amíg a megyeszékhelyen elsősorban a zaj, addig a járás településein a dohos, vizes és gombás lakások jelentenek gondot a lakosoknak. Feltehetően a lakásállomány összetételének ismeretében közelebb jutnánk a háttérben húzódó okok megértéséhez. A lakások korára és építési technológiájára nem találtam adatokat, így csupán feltételezem, hogy a Nyíregyházi járás falvaiban a régi építésű lakásoknál gyakrabban fordulnak elő egészségre ártalmas állapotok. A városban élők a nyugalom hiányára és a zajos, autóforgalommal terhelt lakásokra jobban panaszkodnak, mint a falvakban élők.

A lakástól távolodva a lakóhely problémáinál ugyancsak eltérés látható a megyeszékhely és a járás települései között. A megyeszékhelyen élőket a lakásukhoz közeli, hangos környezet zavarja leginkább, minden ötödik lakos olyan lakókörnyezetben él, ahol forgalom, ipari létesítmény, üzlet miatt emelkedik a zajszint. A nyíregyházi lakosság egyhatodánál a légszennyezés okoz problémát a lakókörnyezetben. Odafigyelésre késztető adat a vandalizmus megítélése a környezetben. A nyíregyháziak egytizede említi a környezet rongálását problémaként. Minden más, a lakásokban keletkező probléma csekély gyakorisággal fordul elő, így például a Nyíregyházi járás településein élők egyhetedénél jelent gondot a hangos környezet. A falvak alapvetően zajmentes környezete jelenti a településeken élő lakosság nyugalmát.

\footnotetext{
${ }^{15}$ A programok ismertetése a szervezetek honlapján elérhető: http://www.habitat.hu/hu/mitcsinalunk/ és http://avarosmindenkie.blog.hu/
} 


\section{A lakások felszereltsége}

A lakáshoz tartozó javak a civilizációs fejlődés eszközei, olyan tárgyak, amelyekre a mindennapi életben szükségünk van. Ezek között csupa olyan háztartási, elektronikai és egyéb eszközről van szó, melyek megkönnyítik a kommunikációt, a háztartási munkát, az utazást és a pihenést.

\section{9. sz. ábra: Elektronikai eszközök a lakásban (\%)}

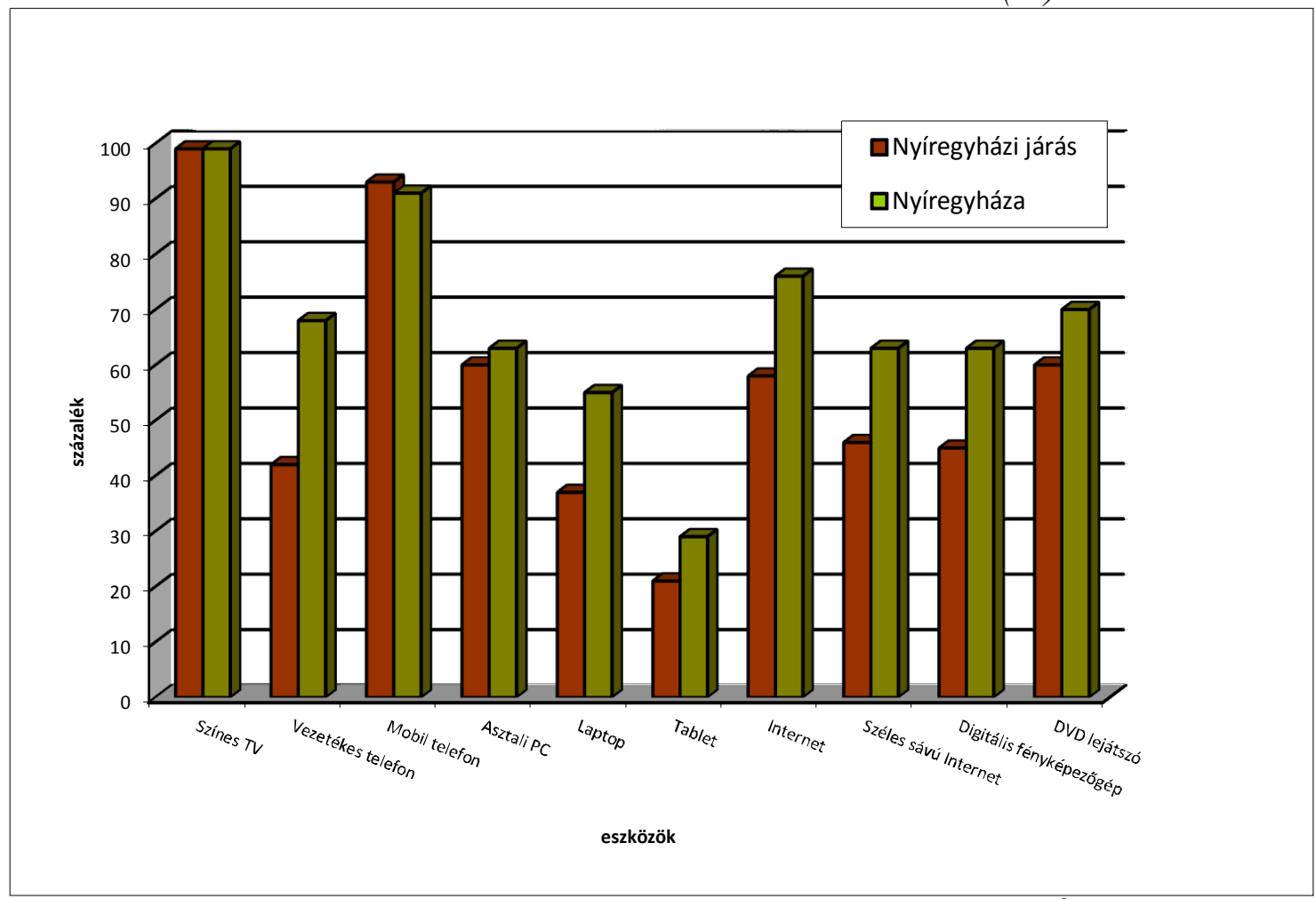

Forrás: Nyíregyháza Életminősége 2015.

Az elektronikai eszközök közül a színes televízió minden lakásban megtalálható. Az információs technológiai eszközök közül messze magas arányban találjuk meg a mobiltelefont a lakosságnál. Mobil készüléket 90 \%-ban birtokolnak a lakosok mindkét területen. Vezetékes telefon kétszer annyi van a nyíregyházi lakosoknál, mint a járás településein élőknél. A kommunikáció és az információ szerzés internetes elérése a járás lakosságának 60 százalékánál, a nyíregyházi lakososok 75 százalékánál megoldott. Szélessávú internet elérésre a nyíregyháziaknak jobbak a lehetőségei, a lakosok 60 százaléka csatlakozik széles sávon az internethez, míg a járás lakosai 40 százalékban használják ezt a szolgáltatást. A modern számítástechnikai eszközöket tekintve az asztali számítógépekkel való ellátottság hasonló arányokat mutat, mindkét területen a lakosok 60 százaléka rendelkezik ezzel az eszközzel. A hordozható számítástechnikai eszközök tekintetében a nyíregyházi lakosoknál több laptop és tablet található, mint a járásban élöknél. Szórakozást jelentő eszközök, mint digitális fényképezőgép és DVD lejátszó több nyíregyházi háztartásban van, mint járási településen. 


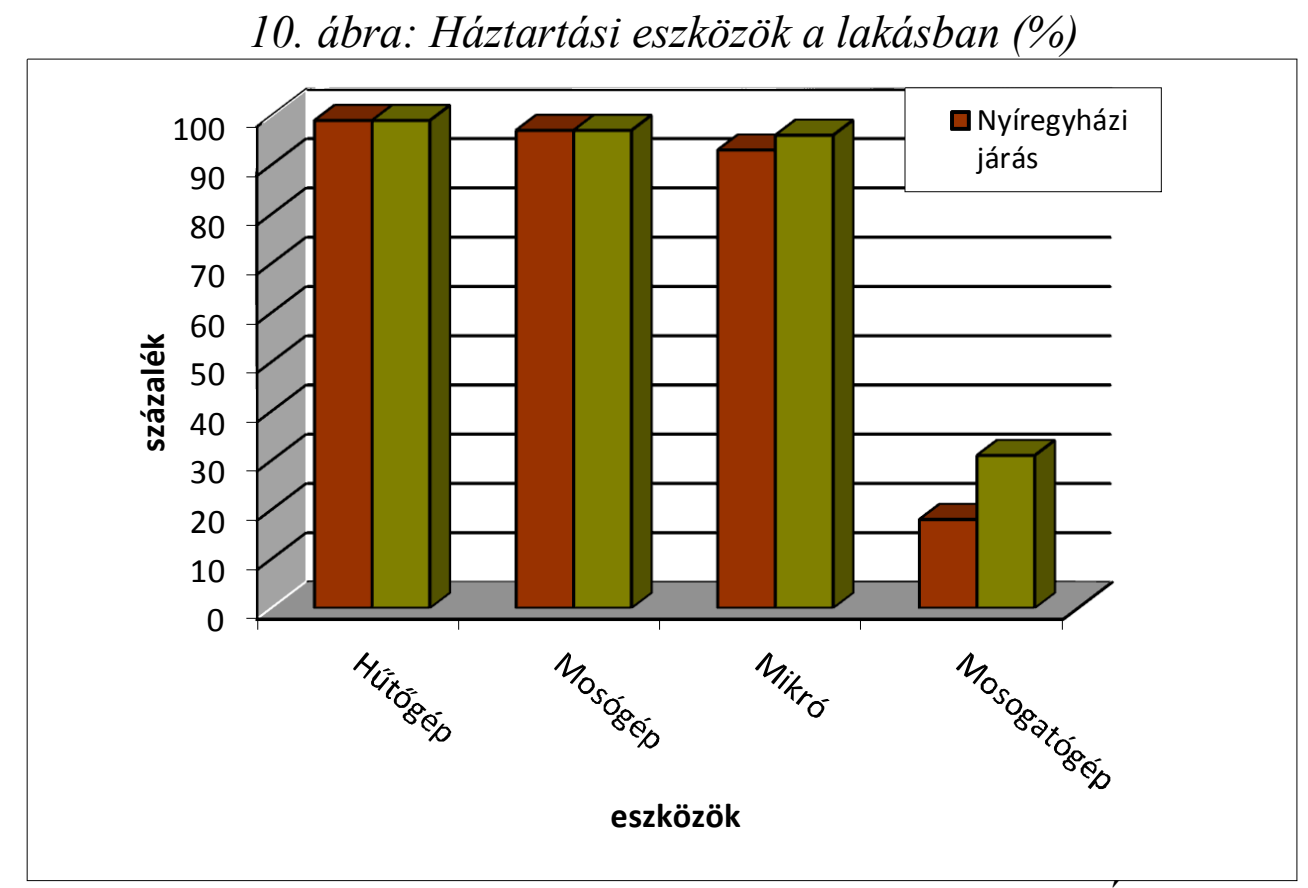

Forrás: Nyíregyháza Életminősége 2015.

A háztartási gépek közül a hütőgép, a mosógép és a mikrohullámú sütő szinte minden háztartásban megtalálható úgy a járás településein, mint Nyíregyházán. Ezek az eszközök elemi szinten épültek be az emberek életébe. Kivételként tekinthetünk a mosogatógépre, ami nem tartozik a létfenntartást elsődlegesen segítő eszközök közé. Bár a mosogatógép fogyasztói árát és hasznosságát tekintve ma már nem annyira tekinthető luxuscikknek, mint egy évtizeddel korábban, ennek ellenére a nyíregyházi háztartások egyharmadában, míg a járási települések háztartásainak egyötödében található meg ez az eszköz.

11. ábra: Vagyontárgyak (\%)

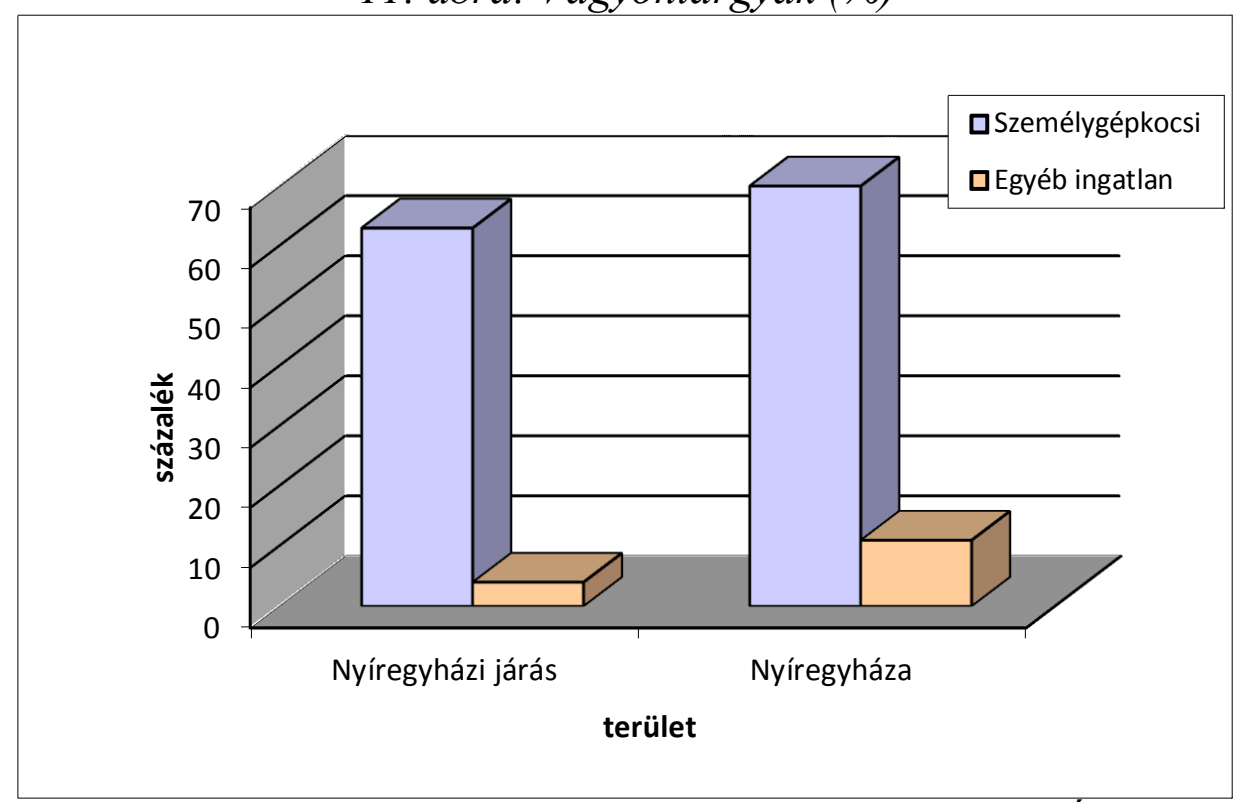

Forrás: Nyíregyháza Életminösége 2015. 
A személygépkocsival rendelkezők arányában nincs nagy különbség a járás és a megyeszékhely között. A nyíregyházi lakosok 70 százalékának háztartásaiban megtaláljuk a személygépjármüvet, míg a járásban élők 63 százaléka birtokolja ezt a fogyasztási cikket. Visszautalva a megyeszékhely vonzó gazdasági és oktatási helyzetére, a járás településein élőknek szükséges eszköz a személygépkocsi munkába és iskolába járáshoz. Egyéb ingatlannal (nyaraló, hétvégi ház) jobbára a nyíregyháziak rendelkeznek, a lakosok körülbelül 10 százalékának van ilyen vagyontárgya.

12. ábra: Nyíregyházi lakásokfelszereltsége 2008 - 2015 (\%)

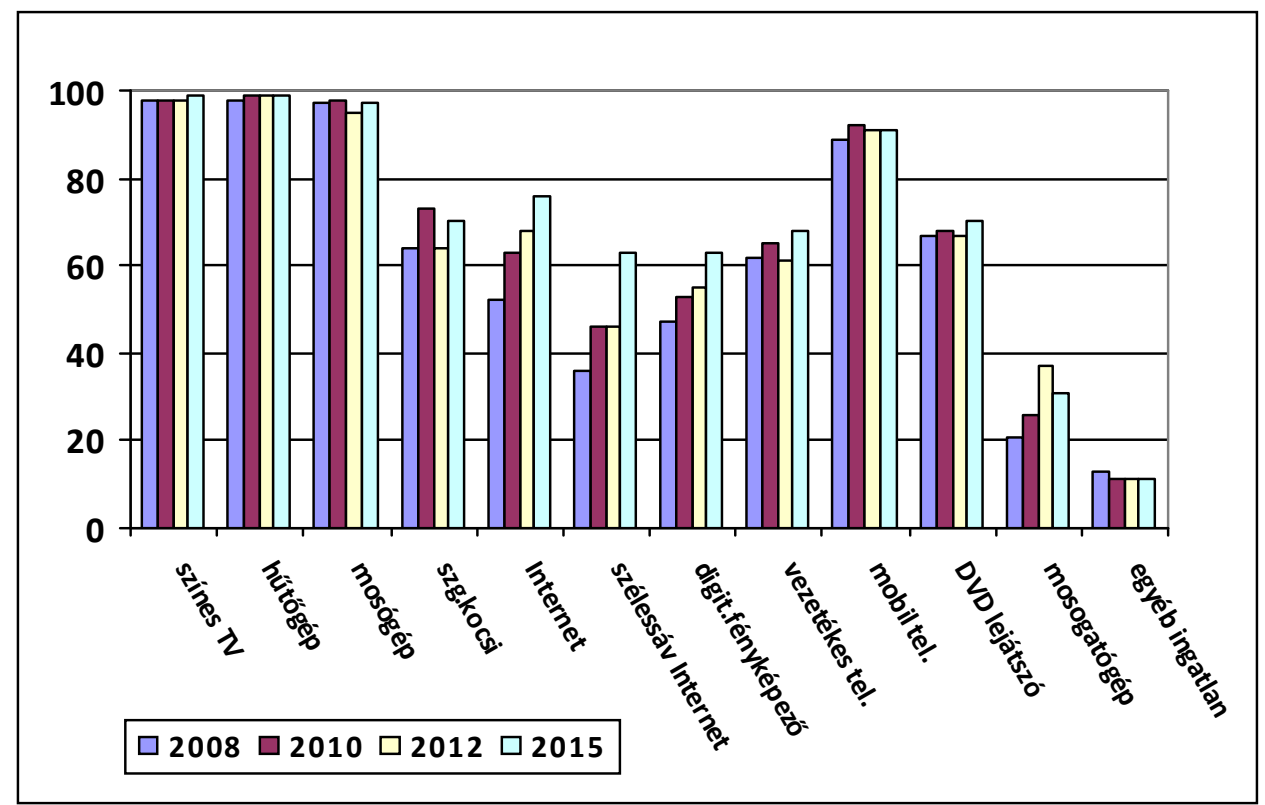

Forrás: Nyíregyháza Életminősége 2015.

A nyíregyházi lakások felszereltségében számottevő változás nem mutatkozik az előző adatfelvételhez képest. A jövő infokommunikációjához előrelépést jelent az internet és a szélessávú internet elérésének bővülése a háztartásokban. Erre vonatkozó fejlesztés napjainkban is zajlik a megyeszékhelyen.

\section{Összegzés}

A lakásállomány növekedése részben a piaci mozgásokon, részben az állam és az önkormányzat bérlakás-építési szándékain múlik. Az országosan évi 8-10 ezer új lakás építése roppant kedvezötlen adat a lakhatási szükségletek kielégítéséhez. Az önkormányzatok hasonlóan elönytelen pozícióban vannak a bérlakás-állomány bővítésében. A lakhatási szükségletek kielégítetlensége olyan társadalmi csoportoknál, akiket a lecsúszás, a szegénység, a hiteltartozás és a hajléktalanság masszívan lakhatási szegénységben tart, roppant módon kedvezőtlen. Szükség van olyan települési lakáskoncepció elkészítésére, melyben az önkormányzati és az üresen lévő lakásállomány korszerüsítésére, megfizethetőségére és hasznosítására is kitér az önkormányzat, ezzel középtávon csökkentheti a lakhatási szegénységet és esélyt 
teremthet a lakhatást nélkülözőknek. Új eszközként lehetne felhasználni az ún. közösségi lakásépítést, ami növeli a társadalmi felelősségvállalást és szolidaritást a nélkülözők irányába.

\section{Felhasznált irodalom}

1.) Czifrus Márton - Pósvai Zsuzsanna (2015): Kritikus ponton? Önkormányzati lakásgazdálkodás a gazdasági világválság után KSH, Területi Statisztika, 2015, 55(5): p. 484-504. Letöltési hely: http://www.ksh.hu/docs/hun/xftp/terstat/2015/05/czirfusz_posfai.pdf Letöltés: 2015. október 20.

2.) Fábián Gergely - Takács Péter - Szigeti Fruzsina (2015): Jövedelmi helyzet és jövedelmi szegénység Nyíregyháza életminősége 2015 kutatás.

3.) Kardos Gábor: A lakhatáshoz való jog. A nemzetközi jog felfogása és a magyar Alkotmánybíróság határozata. Letöltési hely: http://www.fundamentum.hu/sites/default/files/01-1-07.pdf Letöltés: 2015. október 5.

4.) Koltai Luca szerkesztette (2014): Éves jelentés a lakhatási szegénységről - 2013 Habitat for Humanity Magyarország, 2014. Letöltési hely: http://www.habitat.hu/files/Lakhatasi_Jelentes_ 2013 hosszu.pdf Letöltés: 2015. október 5.

5.) Malakucziné Póka Mária (2015): A Nyíregyházi járás települési szerkezeti, demográfiai, háztartási jellemzői Nyíregyháza életminősége 2015 kutatás.

6.) Misetics Bálint (2013): Javaslatok egy egalitariánus lakáspolitikai reform fö irányaira: politikai és szakpolitikai vázlat Esély, 2013/1. p. 39 - 73.

7.) Szoboszlai Katalin: Lakásjellemzők Nyíregyházán 2012. In: Életminőség Nyíregyházán 2012. Acta Mediciane Sociologica Vol. 5. No. 12-13. 2014. p. 105 - 122.

- A Huszár telep területi és társadalmi reintegrációja. Akcióterületi terv. MEGAKOM, 2012. Letöltési hely: http://adat.nyiregyhaza.hu/eloterjesztes/2012/0426/120424_kozgyules_eloterjesztes_18_huszartelep_2_melleklet.pdf. Letöltés: 2015. október 8.

- Lakásstatisztika, Eurostat adatok Letöltési hely: http://ec.europa.eu/eurostat/statisticsexplained/index.php/Housing_statistics/hu\#A_lak.C3.A1sok_megfizethet.C5.91s.C3.A9geLet öltés: 2015. október 5.

- Lakáshelyzet In: Társadalmi helyzetkép 2010 KSH, 2010. Letöltési hely: https://www.hu/ docs/hun/xftp/idoszaki/thk/thk10_lakas.pdf. Letöltés: 2015. október 21.

- Nyíregyháza Megyei Jogú Város Településfejlesztési Koncepciója, 2014. Letöltési hely: http://adat.nyiregyhaza.hu/eloterjesztes/2014/0626/140619_kozgyi_eloterj_04_3mell.pdf. Letöltés:2015. október 5.

- Nyíregyháza Megyei Jogú Város Esélyegyenlőségi program 2011 - 2016. Letöltési hely: http://adat.nyiregyhaza.hu/adattar/2011/hatarozat/110707_H_127.pdf. Letöltés: 2015. október 5.

- Szociális lakásgazdálkodás (2203 - 2015) KSH. Letöltési hely: http://www.ksh.hu/ thm/2/indi2_7_7.html. Letöltés: 2015. október 8.

\footnotetext{
A szerző

Szoboszlai Katalin szociális munkás, a Debreceni Egyetem Egészségügyi Kar tanszékvezető docense. Kutatási területe a hajléktalanság és a szegénységgel összefüggésbe hozható társadalmi csoportok szociális helyzete. A „Nyíregyháza életminősége - háztartáspanel” vizsgálatban 2008-tól elemzi a lakhatással kapcsolatos adatokat.
} 